Reprinted from G. Russell, B, Marshall and P. G. Jarvis (eds.) (1988) Plant canopies: Their Growth, Form and Function.

SEB Seminar Series, 31

(C) Cambridge University Press, 1989 



\author{
H. VAN KEULEN, J. GOUDRIAAN AND \\ N.G. SELIGMAN
}

\title{
5. Modelling the effects of nitrogen on canopy development and crop growth
}

\section{Introduction}

Green plants utilise the sun's energy to synthesise organic compounds from carbon dioxide and water. The pioneering work, concurrently carried out by Liebig in Germany and Lawes \& Gilbert in the UK. more than a century ago, conclusively showed that plants must take up inorganic nutrients from the soil to produce these organic components. Since that discovery it has been established that many elements are necessary for optimum functioning of the biochemical machinery of the plant. Most of these are necessary in such small amounts, however, that the supply from the seed, or from natural sources suffices. In agriculture the situation is often different for the macro-elements nitrogen, phosphorus and potassium that are needed in such large quantities, especially where crop management practices aim at very high yields, that the supply from natural sources falls far short of the demand. Fertiliser experiments show that, up to a certain level, addition of these elements from a fertiliser bag leads to higher yields. Unfortunately, interpretation of these fertiliser experiments seldom exceeds the derivation of the optimum nutrient application rate for the conditions of the experiment, either in physical or in economic terms. The lack of explanatory conclusions hinders the use of such results for predictive purposes, for example, in the formulation of fertiliser recommendations for the farmer. This lack of predictive power is especially serious in the case of nitrogen where at present the price of the fertiliser in western economies does not encourage restricted use by the farmer, but where the cost to society, because of air and water pollution due to excessive application of both organic and inorganic manures, may become prohibitive.

A more promising approach would seem to be to describe the effects of nitrogen or its deficiency in terms of the processes that determine crop growth and yield, for example canopy development, and to predict on that basis the nutrient requirements for a certain target yield (Greenwood, 1982). In this chapter we have used an analysis of growth of spring wheat crops as an example of this approach. However, despite more than 100 years of research in the field of plant nutrition, many of the required relationships appear to be either totally absent or, at best, ambiguous. Nevertheless, some results are presented from a model in which these relations have been incorporated in a coherent framework. 
The principles underlying the description of the nitrogen economy of the crop would in our view also be applicable for other annual crops. In many instances it appeared that the relationships used were identical for different species. Perennial species behave differently in that recirculation of nitrogen between above- and belowground plant parts is an important process.

\section{The relationship between nitrogen status and dry matter production}

Dry matter production, either the total or that accumulated in a specific plant part such as the tubers or the grains, is the product of the length of the production period and the mean rate of dry matter accumulation during that period. The effect of nitrogen on crop performance can thus be described by accounting for its effect on both components.

\section{Length of the growing period}

The phenological development of the plant, i.e. the rate and order of appearance of vegetative and reproductive plant organs, is governed both by genotype, and by environmental factors, notably day length and temperature (van Dobben, 1962a). For at least some cultivars of spring wheat the effects of day length are insignificant and, moreover, for most environments cultivars are available that suit the particular photoperiodic characteristics of that environment. The driving force for development then becomes temperature and the relevant variable is the temperature of the stem apex which can be approximated by either air or canopy temperature.

Nitrogen deficiency may cause stomatal closure at higher plant water potentials (Radin \& Ackerson, 1981), or a reduction in water uptake by increased root resistance (Radin \& Boyer, 1982) and a consequent reduction in transpiration (Shimshi, $1970 a ; b$; Shimshi \& Kafkafi, 1978) which will alter the energy balance of the canopy and hence its temperature. In the field, differences of up to $4{ }^{\circ} \mathrm{C}$ in canopy temperatures have been measured between fields optimally supplied with $\mathrm{N}$ and fields under nitrogen stress (Seligman, Loomis, Burke \& Abshahi, 1983). Under certain climatic conditions an indirect effect of nitrogen shortage on phenological development can thus be expected. Such effects have indeed been reported where a field-grown crop of wheat under nitrogen deficient conditions reached maturity up to 5 days earlier than a crop growing with adequate nitrogen (Seligman et al., 1983). This delay is equivalent to somewhat less than $1^{\circ} \mathrm{C}$ temperature difference during the main growing period between booting and early grain fill.

Severe stress can of course stop development completely, although it is not clear at what point this can happen. This phenomenon may be the basis of the observation that relatively severe stress can delay phenological development (Angus \& Moncur, 1977).

The effect of nitrogen status on the actual transpiration of a wheat canopy is discussed in more detail later in this chapter. 


\section{Dry matter production}

Carbon dioxide assimilation by the leaf canopy. The influence of nitrogen deficiency in the vegetation on dry matter accumulation, total production, and yield is well documented, but the effects on the basic processes of assimilation and respiration are far less clear. The rate of $\mathrm{CO}_{2}$ assimilation at different levels of nitrogen concentration in the leaves has been determined for many plant species, such as maize (Zea mays) (Goudriaan \& van Keulen, 1979; Ryle \& Hesketh, 1969), sunflower (Helianthus annuus) (Goudriaan \& van Keulen, 1979), cotton (Gossypium hirsutum) (Wong, 1979; Ryle \& Hesketh, 1969), sugar beet (Beta vulgaris) (Nevins \& Loomis, 1970), rice (Oryza sativa) (Cook \& Evans, 1983a,b; Yoshida \& Coronel, 1976; Takeda, 1961), pasture grasses, both those with $\mathrm{C}_{3}$ and $\mathrm{C}_{4}$ photosynthetic pathways (Woledge \& Pearse, 1985; Bolton \& Brown, 1980; Lof, 1976; Wilson, 1975a,b), wheat (Triticum aestivum) (Marshall, 1978; Osman, Goodman \& Cooper, 1977; Dantuma, 1973; Osman \& Milthorpe, 1971; Khan \& Tsunoda, 1970a,b), soya bean (Glycine max) (Boon-Long, Egli \& Leggett, 1983; Lugg \& Sinclair, 1981; Boote, Gallaher, Robertson, Hinson \& Hammond, 1978), Eucalyptus spp. (Mooney, Ferrar \& Slatyer, 1978) and tung Aleurites sp. (Loustalot, Gilbert \& Drosdoff, 1950). In all situations where nitrogen concentration of the leaves was determined, there was a strong correlation between the nitrogen concentration in the leaves and their photosynthetic performance.

Leaf nitrogen concentration can be expressed either on an area basis or on a dry weight basis. In the literature cited above, both methods have been used, but where the specific leaf area is reported, the data can be expressed on a common basis. In Fig. 5.1 some data for $C_{3}$ species are summarised from situations where the applied photon flux density during the measurements was high enough to ensure light saturation. The data suggest a linear relation between nitrogen concentration and net $\mathrm{CO}_{2}$ assimilation rate, at least up to a nitrogen concentration of $0.06 \mathrm{~kg} \mathrm{~kg}^{-1}$. Some of the residual variability could be due to different ages or development stages of the experimental material. Net assimilation becomes zero at a nitrogen concentration of $3.8 \mathrm{~g} \mathrm{~kg}^{-1}$.

Net $\mathrm{CO}_{2}$ assimilation as a function of nitrogen concentration expressed on an area basis is given in Fig. 5.2. Zero assimilation occurs in this case at a nitrogen concentration of $0.2 \times 10^{-4} \mathrm{~kg} \mathrm{~m}^{-2}$. The two slopes would be identical at a value of the specific leaf area of $31.25 \mathrm{~m}^{2} \mathrm{~kg}^{-1}$, a rather high value, suggesting that most experiments were conducted on young, thin leaves.

The general conclusion from the data presented here is thus that the maximum rate of carbon dioxide assimilation is linearly related to nitrogen concentration over a wide range of concentrations. Sometimes in individual experiments a 'saturation'-type curve seems more appropriate, but that is difficult to derive from the bulked data.

No significant effect of leaf nitrogen concentration on the light use efficiency at low irradiance has been shown (Cook \& Evans, 1983a,b; Wilson, 1975a,b) but it is 
Fig. 5.1. The relation between nitrogen concentration in the leaf blade (on a dry weight basis) and the maximum rate of net $\mathrm{CO}_{2}$ assimilation. , O Oryza sativa (Yoshida \& Coronel, 1976); $\nabla$ Triticum aestivum (Dantuma, 1973); $\nabla$ Triticum aestivum (Marshall, 1978); ๑ Panicum spp. (Brown \& Wilson,1983); + Hordeum murinum, $\oplus$ Phalaris minor (Lof, 1976); $x$ Lolium perenne (Wilson, 1975); $\square$ Oryza spp. (Cook \& Evans, 1983a,b); tung (Loustalot et al., 1950); \& Festuca arundinacea (Bolton \& Brown, 1980). The calculated regression line $\left(r^{2}=0.77\right)$ has a slope of $22.0 \mathrm{mg} \mathrm{CO}_{2} \mathrm{~m}^{-2} \mathrm{~s}^{-1}$ for each unit increase in nitrogen concentration.

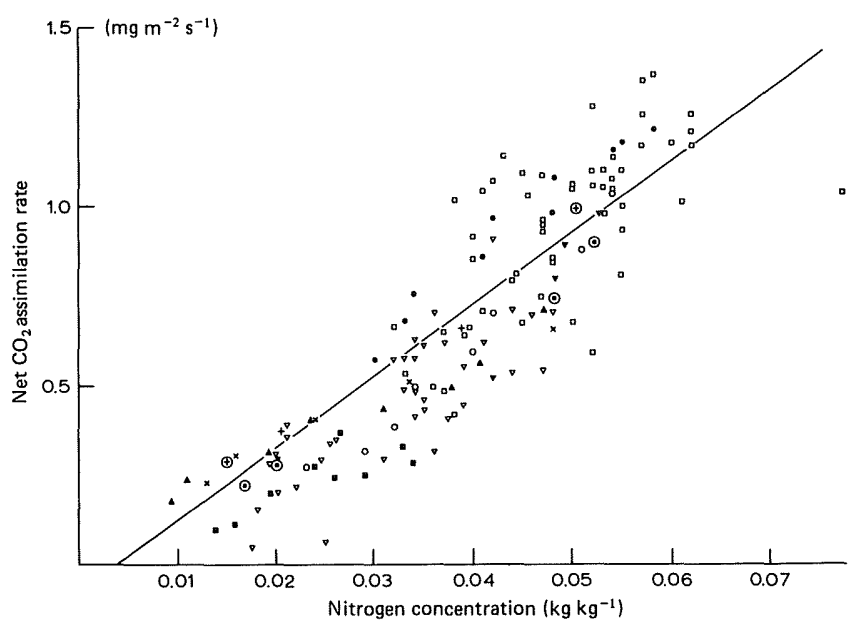

Fig.5.2. The relation between nitrogen concentration in the leaf blade (on an area basis) and the maximum rate of net $\mathrm{CO}_{2}$ assimilation: $\times$ Beta vulgaris (Nevins \& Loomis, 1970); -, O Oryza spp. (Cook \& Evans, 1983a,b), $\Delta$ Oryza sativa (Yoshida \& Coronel,1976); + Glycine max (Boon-Long et al., 1983).The calculated regression line $\left(r^{2}=0.76\right)$ has a slope of $7.1 \mathrm{mg} \mathrm{CO}_{2} \mathrm{~m}^{-2} \mathrm{~s}^{-1}$ for each unit increase in nitrogen concentration.

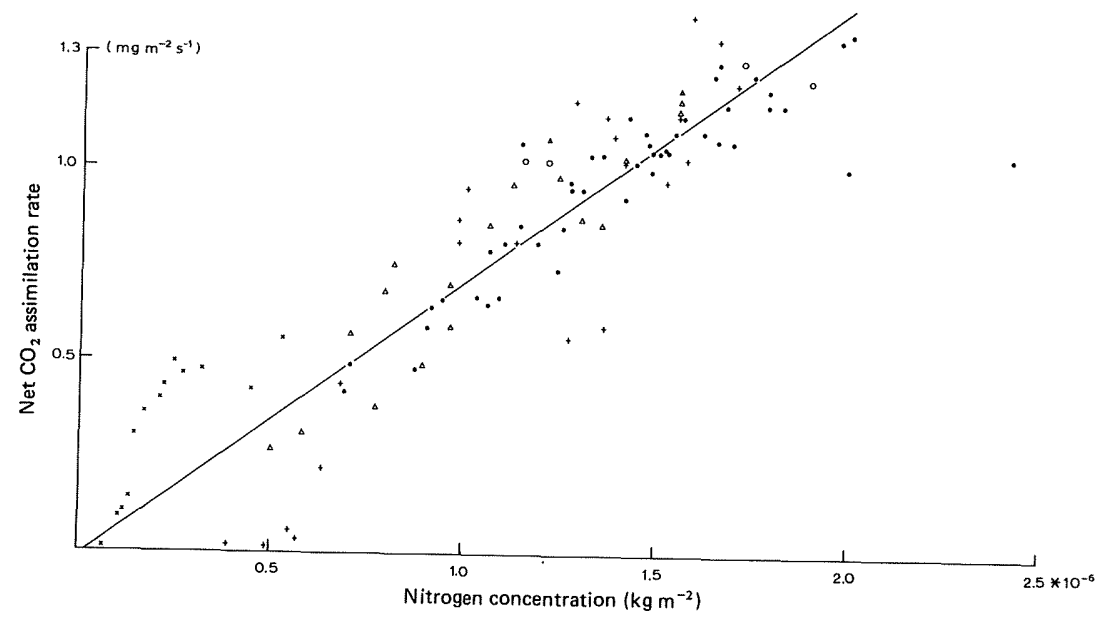


possible that small differences in the slope are responsible for some of the measured differences in assimilation rate between canopies with different leaf nitrogen concentrations. For the time being, the influence of nitrogen concentration on $\mathrm{CO}_{2}$ assimilation can thus be modelled by relating the value of the light saturated $\mathrm{CO}_{2}$ assimilation rate of individual leaves, $F_{\mathrm{m}}\left(\mathrm{kg} \mathrm{CO}_{2} \mathrm{ha}^{-1} \mathrm{~h}^{-1}\right)$, to the nitrogen concentration in the leaf blades, $N\left(\mathrm{~kg} \mathrm{~kg}^{-1}\right)$ :

$$
F_{\mathrm{m}}=725 N-2.75 ; F_{\mathrm{m}}>0
$$

Partitioning of assimilates between respiration and growth of various organs. The assimilates fixed in the photosynthetic process are used in various processes in the plants including maintenance respiration. Sink strength, which is probably related to the number of growing cells in a particular organ (Sunderland, 1960), is an important determinant of assimilate distribution at any time.

Maintenance of the various living plant parts has presumably first priority. Maintenance respiration depends of the weight of an organ, its chemical composition, particularly its nitrogen concentration (reflecting the rebuilding of continuously degrading proteins) and the ambient temperature (Penning de Vries, 1975). In the model for each organ, i.e. roots, leaves, stems and grains, the carbohydrate requirement of maintenance respiration is calculated first. Although quantitative estimates of maintenance respiration have been proposed, a great deal of uncertainty still exists and in some cases it has been necessary to introduce 'fudge' factors to describe reality sufficiently well (de Wit et al., 1978).

The effect of nitrogen concentration on maintenance respiration is accounted for by a multiplication factor that ranges between 1 and 2, which is about the range found in maintenance requirements per unit dry weight between protein-poor and protein-rich materials (Penning de Vries, 1975). Although quantitative information is rather scarce (Hanson \& Hitz, 1983), protein turnover is presumably low at very low nitrogen concentrations, and in any case has a small energy requirement compared to that needed for maintenance of the ionic balance within the cells and the transport of assimilation products.

The assimilates remaining after subtraction of the maintenance requirements of the live organs of the crop, are available for the production of structural plant material and are allocated to five compartments: leaf blades, stems and leaf sheaths, roots, grains and a reserve pool of primary photosynthetic products. When growth conditions are optimum, the proportion of net assimilate allocated to each compartment is a function only of the phenological state of the vegetation, representing the varying sink strengths of the various organs. When growing conditions are sub-optimum the partitioning changes. Whether this is an active process, or the result of a differential influence of stress on the growth of different organs is difficult to judge. 
Brouwer $(1963 ; 1965)$ suggested that the conversion of primary photosynthates into above-ground structural plant material is more inhibited by insufficient moisture supply than is $\mathrm{CO}_{2}$ assimilation. As a result, the level of reserve carbohydrates in the plant increases and this increases their availability for growth of the root system. As a consequence, water shortage changes the partitioning of assimilates between shoot and root. Brouwer referred to this phenomenon as the 'functional balance'.

Nitrogen shortage in the vegetation also favours the growth of roots at the expense of above-ground material (Cook \& Evans, 1983a; Campbell, Davidson \& Warder, 1977; Wilson \& Haydock, 1971; Colman \& Lazenby, 1970; Brouwer, 1965; Brouwer, Jenneskens \& Borggreve, 1962; McLean, 1957), which may be the result of the same functional balance. The partitioning between leaf blades and other aboveground organs also changes in nitrogen deficient conditions and generally results in a lower leaf weight ratio (Campbell, Davidson \& McCaig, 1983; van Os, 1967; McNeal, Berg \& Watson, 1966; Boatwright \& Haas, 1961). However, the instantaneous effect of sub-optimum nitrogen concentrations in the tissue on partitioning of assimilates is difficult to quantify from existing experimental data. In the model, nitrogen stress at any particular point in time is defined as the difference between the maximum nitrogen concentration at a certain development stage and the actual nitrogen concentration, expressed as a fraction of the range between the maximum and the minimum nitrogen concentration.

These influences can thus be described schematically by assuming a growth check on the shoot compartments (leaf blades and stem) when nitrogen shortage occurs. The resulting 'surplus' carbohydrate is partitioned between roots and the reserve pool. When stress is alleviated and reserve carbohydrates have accumulated, some can become available for subsequent leaf growth.

Conversion of assimilates into dry matter. The assimilates allocated to the various sinks are a mixture of carbohydrate and nitrogenous compounds. These primary products must be converted into structural plant material, and the energy required for this conversion must be taken into account. The magnitude of this growth respiration also depends on the chemical composition of the material being formed (Penning de Vries, Brunsting \& van Laar, 1974; Penning de Vries, 1974). As a first approximation the composition can be defined in terms of protein and carbohydrate only, as these components constitute the major part of the plant material. Since the proteins are assumed to be formed from nitrates only the costs of reduction have to be taken into account.

The rate of increase in plant dry weight is thus obtained by dividing the rate of assimilate supply by the specific assimilate requirement factor. The latter is defined as 1.21 times the fraction of carbohydrates in the currently formed material plus 2.27 times the fraction of proteins (Penning de Vries, 1974). These values, based on detailed biochemical pathway analysis are reasonably well-established, but the 
uncertainty in this case originates mainly from the assumption that all proteins are formed from nitrate. This description results in higher conversion efficiencies for tissues with a lower nitrogen concentration.

\section{The effect of nitrogen status on transpiration}

The actual rate of transpiration of a canopy depends on the potential rate, dictated by meteorological conditions, and on the availability of water in the rooted soil profile.

Many studies have indicated that water use efficiency, i.e. the amount of dry matter produced per unit of water consumed, increases with higher nitrogen availability (van Keulen, 1975; Black, 1966; Viets, 1962). Interpretation of these results is difficult when no distinction has been made between transpiration by plants and evaporation from the soil surface. Plants growing under nitrogen stress generally have a much smaller leaf area than plants growing under optimum nutrient conditions, and so canopy closure occurs much later. Consequently, a larger proportion of water is lost directly from the soil surface, so water use efficiency is reduced. In the early experiments on water use, where direct evaporation from the soil surface was prevented, moderate nitrogen stress had hardly any effect on water use efficiency (Tanner \& Sinclair, 1983; de Wit, 1958).

Recent experiments where assimilation and transpiration of plant species were determined on individual leaves with different nitrogen concentrations, have confirmed the latter hypothesis for maize (Goudriaan \& van Keulen, 1979; Wong, Cowan \& Farquhar, 1979) and Panicum maximum (Bolton \& Brown, 1980), but not for tall fescue (Festuca arundinacea) and Panicum milioides (Bolton \& Brown, 1980). In the latter species the ratio of apparent photosynthesis to transpiration increased almost twofold over a range of nitrogen concentrations in the leaf from 0.01 to 0.05 $\mathrm{kg} \mathrm{kg}^{-1}$.

A comprehensive study of the interactions between nitrogen and water stress, mainly in cotton, has been conducted by Radin and associates (Radin, 1983; Radin \& Boyer, 1982; Radin \& Ackerson, 1981; Radin \& Parker, 1979a,b). They found that in nitrogen-deficient plants stomatal closure occurs at much higher plant water potentials than in plants adequately supplied with nitrogen, i.e. at values of $-1 \mathrm{MPa}$ compared with $-1.8 \mathrm{MPa}$ (Radin \& Ackerson, 1981). On days of high irradiance the leaf water potential of well-watered wheat plants can remain below $-1 \mathrm{MPa}$ for most of the day (Hochman, 1982; Martin \& Dougherty, 1975).

Shimshi $(1970 a, b)$ has shown that transpiration from nitrogen-deficient plants is reduced at high levels of soil moisture, but that near wilting point the situation is reversed, possibly because the much higher proportion of cell wall constituents in the nitrogen-deficient plants reduces stomatal sensitivity. Consequently, not only is stomatal opening restricted under soil moisture conditions, but full stomatal closure is prevented near wilting point. Evidence for greater stomatal opening with better 
nitrogen nutrition has also been found in rice (Ishihara, Ebara, Hirawasa \& Ogura, 1978; Yoshida \& Coronel, 1976), wheat (Shimshi \& Kafkafi, 1978), sunflower and maize (Goudriaan \& van Keulen, 1979).

Radin \& Boyer (1982) have shown that root conductivity is lower in nitrogendeficient sunflower plants. Lower turgor may occur leading to stomatal closure. Lower transpiration rates due to nitrogen deficiency may either be caused by stomatal closure at higher leaf water potentials or by lower root conductivity. In the former case moisture stress would be secondary and possibly minor compared to nitrogen stress; in the latter case moisture stress induced by nitrogen deficiency would be dominant.

Data on the relation between leaf conductance to water vapour and leaf nitrogen concentration for rice have been published by Yoshida \& Coronel (1976). Fig. 5.3 is derived from their data and relates leaf conductance to nitrogen concentration in the leaf. In these data, leaf conductance includes boundary layer conductance, so that stomatal conductance would necessarily be to the left of the regression line. There appears to be a linear relationship between leaf conductance and nitrogen concentration in the leaf. Such a relation suggests stomatal control through the $\mathrm{CO}_{2}$ concentration in the sub-stomatal cavity (Goudriaan \& van Laar, 1978). In that case, stomatal opening is regulated in such a way that the $\mathrm{CO}_{2}$ concentration either remains constant or has a

Fig. 5.3. The relation between the nitrogen concentration in the leaf blade and total conductance for water vapour exchange for individual rice leaves (Source: Yoshida \& Coronel,1976).

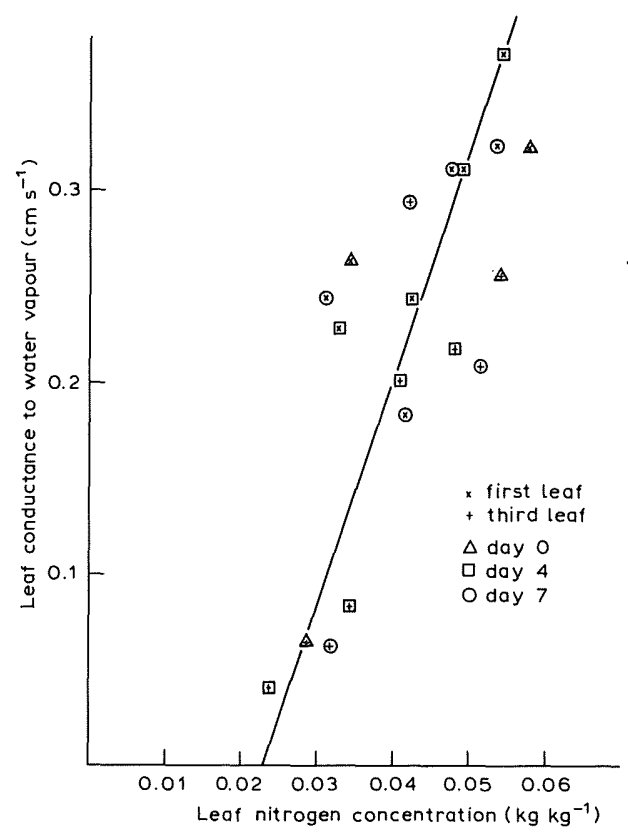


fixed ratio to the external concentration. Any impairment of assimilation will lead then to proportional stomatal closure and decreased transpiration. It is, however, not yet clear under what conditions this phenomenon can be expected in the field.

The effect of nitrogen shortage on water use is therefore difficilt to predict and must be carefully reconsidered for each situation.

\section{Nitrogen in the plant}

\section{Nitrogen uptake}

Uptake of nitrogen is dependent on both the demand by the plant and on the availability of nitrogen in the soil. Nitrogen is needed in the plant for synthesis of new tissue, so that as plant weight increases the demand for nitrogen increases. As more structural carbohydrate is accumulated, however, the ratio of nitrogen to total biomass in each of the plant parts falls, even when nitrogen is available in surplus (Vos, 1981; Seligman, van Keulen, Yulzari, Yonathan \& Benjamin, 1976; Dilz, 1964; van Burg, 1962 ; van Dobben, $1962 b ; 1960$ ). When nitrogen supply is non-limiting, there is a negative linear relationship between the nitrogen concentration in plant organs and the development stage of the crop. The total nitrogen concentration in the leaves falls from an initial value of about $0.06 \mathrm{~kg} \mathrm{~kg}^{-1}$ to $0.02 \mathrm{~kg} \mathrm{~kg}^{-1}$ at maturity. The nitrogen concentration in stem tissue falls from around $0.03 \mathrm{~kg} \mathrm{~kg}^{-1}$ at the onset of stem elongation to about $0.008 \mathrm{~kg} \mathrm{~kg}^{-1}$ at maturity. Maximum nitrogen concentrations in the root are more variable than in the shoot. Appropriate values under conditions of surplus supply from the soil would be about $0.035 \mathrm{~kg} \mathrm{~kg}^{-1}$ at seedling emergence and $0.01 \mathrm{~kg} \mathrm{~kg}^{-1}$ at maturity.

In the model, the nitrogen demand of any plant part at any point in time is defined as the difference between the maximum amount attained under optimum nitrogen supply and the actual amount in the tissue at that moment. The total nitrogen demand of the canopy is then the sum of the nitrogen demands of the component parts or organs, i.e. the leaves, stem and roots. Grain nitrogen is assumed to be supplied by translocation from the vegetative organs and so does not contribute directly to nitrogen demand.

Availability of nitrogen to the vegetation depends both on the amount present in the soil and on the extent and density of the plant's root system (van Keulen, Seligman \& Goudriaan, 1975). In the wheat crop, rooting density is generally relatively high, i.e. greater than $1 \mathrm{~cm}$ root length $\mathrm{cm}^{-3}$ soil (e.g. Gajri \& Prihar, 1985; Lupton, Oliver, Ellis, Barnes, Howse, Welbank \& Taylor, 1974), and so most of the mineral nitrogen in the rooted zone is available for uptake within one day and virtually all within two days, provided that all or the greater part of that nitrogen is present in the form of nitrate. Consequently, diffusion can supply the balance between demand and mass flow even when mass flow is very low. Early in the season, before the root system of the crop is fully expanded horizontally, some of the soil nitrogen within the rooted depth may be unavailable. This is modelled by defining a maximum uptake rate 
determined by the extent of the root system. Daily nitrogen uptake is defined as the demand of the crop, the amount available in the soil or the maximum uptake rate, whichever is the highest. This formulation implies that uptake cannot exceed demand, so that if demand is satisfied, excess nitrogen reaching the root surface in the transpiration stream is excluded. This phenomenon has been observed in experiments with plants grown in nutrient solutions, where total uptake levels off beyond a certain concentration of nitrogen in the solution even though transpiration continues (cf. Alberda, 1965) and also in the field where uptake by the vegetation levels off at high application rates (cf. Prins, Rauw \& Postmus, 1981).

\section{Distribution of nitrogen in the plant}

The nitrogen taken up by the plant is partitioned between leaves, stems and roots in proportion to their relative demand. When supply cannot satisfy the total demand, roots do not have first priority despite their closeness to the source (van Keulen, 1981; van Dobben, 1963).

As the leaves age, some of their nitrogen can be transferred to tissues where an unsatisfied demand for nitrogen exists. If leaves die because nitrogen shortage has caused senescence, all the nitrogen except for an immobilisable residual amount in the senescing leaf, is translocated to the remaining live tissues. The residual level of nitrogen in the vegetative organs is a function of the development stage of the vegetation, young parts dying with a higher residual nitrogen concentration (Seligman, unpubl. data; Dilz, 1964). If leaves die for reasons other than nitrogen deficiency some of the translocatable nitrogen can be used to satisfy the nitrogen demand of other organs, primarily the stem. In this way the stem serves as a temporary store for nitrogen before translocation to the grain.

\section{Translocation of nitrogen to the seed}

Seeds receive most of their nitrogen in a reduced form, generally as amino acids, from the roots, leaves and stems (Donovan \& Lee, 1978; Nair, Grover \& Abrol, 1978). From various studies it appears that the rate of nitrogen accumulation in the grains can be considered constant during the linear phase of grain growth (Vos, 1981; Donovan \& Lee, 1978; Sofield, Wardlaw, Evans \& Zee, 1977). The rate of accumulation at any moment may be limited by the potential rate of accumulation in the grain (sink) (Donovan \& Lee, 1977; 1978) or by the supply rate from the vegetative parts (source).

The rate of nitrogen depletion from the vegetative parts of the plants is fairly constant as long as the nitrogen concentration in the tissue is above a threshold level of around $0.01 \mathrm{~kg} \mathrm{~kg}^{-1}$ (Dalling, Boland \& Wilson, 1976). Such a constant rate of depletion can be explained as withdrawal from a pool of amino-acids that is maintained at a more or less constant level, when calculated on an integrated daily basis (Hanson \& Hitz, 1983). As the amino-acids are transferred from the vegetative 
tissue to the grain, storage or relatively stable proteins such as RuBPC-ase are mobilized, triggered by a rise in the level of proteolases at the onset of grain growth. The level of proteolases stays relatively high during grain filling and drops only as the grain approaches maturity (Dalling et al., 1976).

As the concentration of nitrogen in the vegetative parts approaches the residual level the rate of depletion drops (Dalling et al., 1976). The rate of transfer from the vegetative tissue and the uptake rate by the seeds are both dependent on temperature with a $\mathrm{Q}_{10}$ value of around 2 (Vos, 1981).

This process of nitrogen depletion in the vegetative parts and translocation to the grain is represented in the model by first defining the maximum nitrogen accumulation rate in the grains as a function of grain number and temperature. The potential export rate from the vegetative tissue is equal to the total nitrogen content above a residual level, multiplied by the relative turnover rate. The latter is influenced by temperature, the moisture status of the vegetation and the level of non-structural carbohydrate.

The actual rate of export is derived from the potential rate, taking into account the 'nitrogen activity' of the vegetative tissue, expressed as its average nitrogen concentration. This conceptualisation makes the notion of competition between vegetative tissue and seed explicit. Thus, if the vegetative tissue is 'active' and has a high nitrogen concentration, its competitive ability is high and the nitrogen is easily retained. The opposite is true in the reverse case. All of these relations are difficult to quantify on the basis of existing insights into the nitrogen economy of plants. Very little experimental work in this field appears to have been done, despite the importance of these processes for green area duration and hence grain yield on the one hand and grain nitrogen concentration, and hence baking quality, on the other. The temperature effect on nitrogen turnover in the plant is well-established and has already been discussed in treating maintenance respiration (Vos, 1981; Penning de Vries, 1975).

The effect of water stress on nitrogen turnover is difficult to disentangle from senescence. During water stressed conditions the nitrogen concentration of the leaf is usually higher (Halse, Greenwood, Lapins \& Boundy 1969; Fischer \& Kohn, 1966; Asana \& Basu, 1963), perhaps because rapid senescence reduces the period available for translocation. Yet, as the tissues senesce, protein breakdown is accelerated. It can therefore be assumed that when the transpiration deficit increases nitrogen turnover increases.

\section{Effect of nitrogen on organ formation}

Leaf area formation. Nitrogen status mainly affects leaf area expansion through the amount of assimilate flowing to the leaves.

In a series of experiments on wheat, Lolium rigidum and Lolium perenne (Greenwood, 1966; Greenwood \& Titmanis, 1966) the rate of leaf area expansion of the youngest expanding leaf was found to be linearly related to the total leaf nitrogen concentration at least for the 58 days duration of the experiments (Fig. 5.4). 
However, whole canopy nitrogen concentration declines with plant development. Because the nitrogen distribution within the live leaf mass is not specified in the model, leaf expansion rate must be related not to the absolute nitrogen concentration in the leaf blades, but to the relative concentration on a scale running from the concentration found in severely depleted leaves up to a maximum concentration dependent on the development stage of the crop.

Under conditions of prolonged nitrogen stress, some of the nitrogen in older leaf blade and sheaths tissue is mobilised, translocated and resynthesised in new organs. The older tissues then die at a rate related to the average nitrogen concentration in the remaining leaf material. Stem tissue also dies under nitrogen shortage, particularly the leaf sheaths concurrent with the death of leaf tissue.

Effect of nitrogen on yield component formation. Formation of yield components, i.e. tillers, ears, spikelets, florets and grains is governed in the model by the assimilate supply necessary to create a viable organ. The effect of nitrogen status of the vegetation on organ formation is therefore mediated largely through its effect on gross assimilation. However, tiller formation is affected directly by the nitrogen status of the vegetation, as well as by assimilate availability (Yoshida \& Hayakawa, 1970; Aspinall, 1961).

For defining the formation rate of the other organs the problem is that the effect of nitrogen status per se and the indirect effects via assimilate availability are difficult to disentangle and very little experimental work appears to have been done to separate the two effects. In one case where such an attempt was made, the direct effect of $\mathrm{N}$ status of the plant appeared to be small (Pinthus \& Millet, 1978).

Fig. 5.4. The relation between the nitrogen concentration in the leaf and the relative rate of leaf area expansion (data points from three experiments).

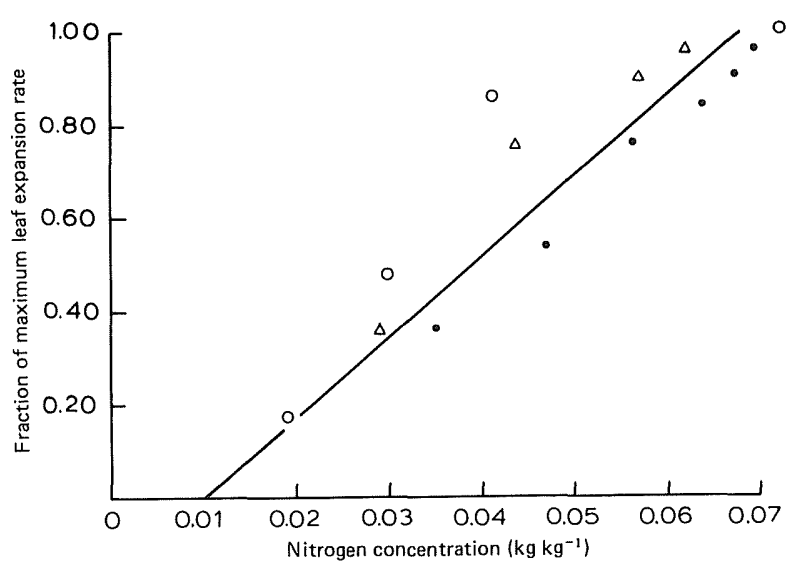




\section{Some quantitive consequences of nitrogen metabolism \\ Yield-uptake and uptake-application relations}

The processes and concepts outlined in the preceding section have been incorporated in a simulation model describing growth and yield of a spring wheat crop (van Keulen \& Seligman, 1987). In this section some results from that model will be discussed, especially with respect to the consequences of the nitrogen economy of the vegetation. The model has been shown to be able to describe with reasonable accuracy the growth and yield of a spring wheat crop under semi-arid conditions in situations where either water or nitrogen is the limiting factor during part of the growing season.

The actual physical environment used in the simulation runs is not directly important, as the major concern is the sensitivity of the model to changes in crop characteristics related to the nitrogen economy. As detailed weather data were available for a site in the northern Negev desert of Israel, collected as part of a research project on actual and potential production in that region (van Keulen, Seligman \& Benjamin, 1981), some of these data were used to drive the model.

In this region irrigated wheat cultivation is practised on a small scale. However, the effects of increased nutrient availability are much more obvious under conditions where other growth factors are close to the optimum. A set of simulation experiments was therefore executed assuming optimum moisture supply throughout the growth cycle of the crop.

First, a fertilizer experiment was simulated, assuming application of fertiliser at the time of sowing either in ammoniacal form or in the form of nitrate. The results presented in Fig. 5.5 show that the relationship between grain yield and nitrogen uptake was independent of the type of fertiliser applied. The maximum yield is approached asymptotically. At low uptake rates about $55 \mathrm{~kg}$ of grain is produced for each $\mathrm{kg}$ of nitrogen taken up. These results agree with experimentally determined response curves (van Keulen \& van Heemst, 1982). The efficiency of nitrogen utilisation $\left(E_{\mathrm{N}}\right)$, expressed as $\mathrm{kg}$ grain produced per $\mathrm{kg}$ nitrogen taken up, is shown in Eqn 2.

$$
E_{\mathrm{N}}=1 /\left(0.01+0.004\left(W_{\mathrm{S}} / W_{\mathrm{g}}\right)\right)
$$

$W_{\mathrm{S}}$ and $W_{\mathrm{g}}$ refer to the weight of straw and grain, respectively. The constants 0.01 and 0.004 are the minimum concentrations of nitrogen in grain and straw, respectively. The efficiency of nitrogen utilization increases with harvest index $\left(W_{\mathrm{g}} /\left(W_{\mathrm{s}}+W_{\mathrm{g}}\right)\right)$ and achieves a value of 55 at a harvest index of 0.33 .

At increasing rates of uptake, the concentration of nitrogen in the harvested product increases and $E_{\mathrm{N}}$ declines. Finally, a plateau level is reached, where increased uptake does not lead to higher yields, because nitrogen is no longer the growth-determining factor, and yield is determined by the combined effect of radiation and temperature. At that point, there is also a tendency for decreasing harvest indices, because abundant 
nitrogen supply in the vegetative stage leads to luxurious vegetative growth and consequently to lower grain/straw ratios.

Nitrogen uptake was proportional to nitrogen application over the full range of application rates tested here, again in accordance with experimental results (van Keulen, 1986; van Keulen \& van Heemst, 1982; van Keulen, 1977). However, a marked difference exists between the nitrate and the ammonium form of nitrogen. The recovery fraction, i.e. the ratio between nitrogen uptake and nitrogen application is 0.39 for the ammonium fertiliser and about 1.0 for the nitrate form.

The difference between the two forms of fertiliser is due to the semi-arid conditions for which the model was developed. Nitrate was assumed not to be subject to denitrification and leaching did not occur due to low rainfall. On the other hand ammonium was subject to volatilisation, which is especially important when fertiliser is applied early in the growing season before the rains have started.

\section{Nitrogen turnover in the vegetative tissue}

The proteins in the vegetative tissue of plants are not stable, but continuously degrade and have to be resynthesised. Unfortunately, only limited information is available on the rate of turnover of proteins, and most of that refers to very young leaves, so that it is questionable whether those data may be applied to mature or senescing leaves. In mature, functioning leaves, where the total protein content is more or less stable, the rate of protein turnover corresponds to breakdown and

Fig. 5.5. The simulated relation between total nitrogen uptake and grain yield, and that between nitrogen application and nitrogen uptake for a spring wheat crop grown in the northern Negev of Israel, for both ammonium $(\odot, \otimes$ and nitrate $(\bullet, \times)$ fertilisers (the cross and dot refer to two separate simulations).

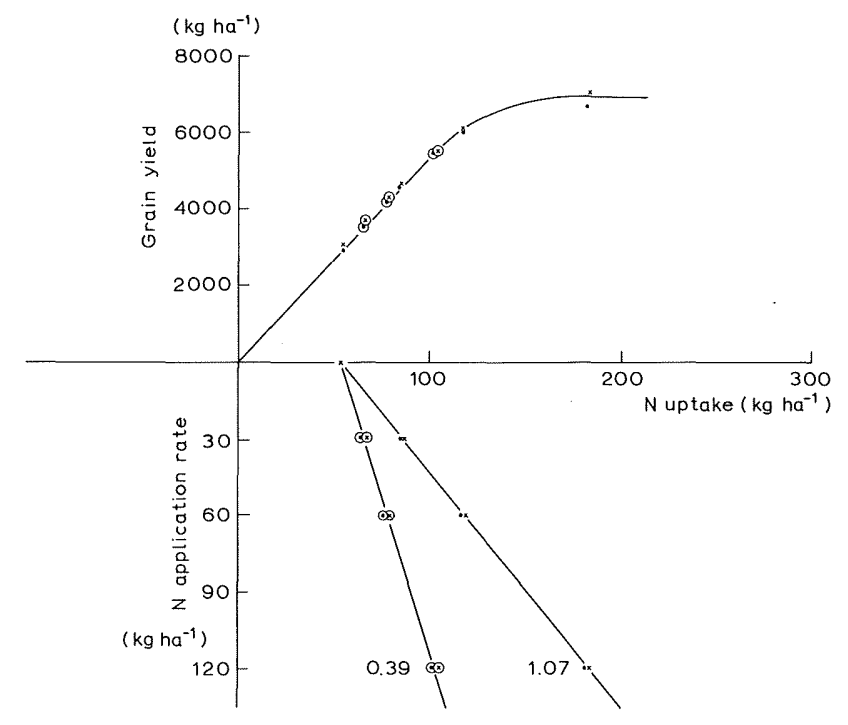


resynthesis of about $10 \%$ of the total protein each day (Penning de Vries, 1975; Huffaker \& Peterson, 1974). In senescing leaves the rate may be higher, either because the 'activity' of the leaves decreases, or because the total protein content of the tissue is declining.

Translocation of nitrogen from the vegetative tissue to the developing grains can only take place if the nitrogenous components are in a form that can be transported, i.e. degraded proteins.

To test the sensitivity of crop performance to increased turnover rates, values of the relative turnover rate between 0.075 and $0.300 \mathrm{~d}^{-1}$ were tested in the model. The results, presented in Fig. 5.6, show that increasing turnover rates lead to both reduced grain and total dry matter yield, so that the harvest index remains more or less constant, except at the highest turnover rate where a slight drop in the harvest index occurs. These lower yields are the result of accelerated export of nitrogen from the vegetative tissue including the leaf blades, to the growing grain, leading to lower photosynthetic capacity and accelerated senescence.

The nitrogen harvest index, i.e. the ratio between total nitrogen in the grain at maturity and total nitrogen in the above ground material increased from $0.315-0.36$ at the lowest turnover rate to $0.63-0.675$ at the highest turnover rate, reflecting the more efficient translocation of nitrogen to the grains. The associated nitrogen concentration in the grains increases from $0.009-0.011 \mathrm{~kg} \mathrm{~kg}^{-1}$ to $0.024-0.029 \mathrm{~kg} \mathrm{~kg}^{-1}$. These results thus indicate a negative relation between grain yield and nitrogen concentration in the grain (Fig. 5.7), in accordance with experimental results in which cultivars with high and low protein content in the grains have been compared (Kramer, 1979; Mesdag, 1979).

An interesting question arising from these results is whether genetic differences between high-protein and low-protein cultivars are the cause of lower yields, or are the result of differences in nitrogen turnover. In view of the interest in high nitrogen

Fig. 5.6. The simulated effect of $(a)$ the relative rate of nitrogen turnover in the vegetative tissue on grain yield and $(b)$ grain nitrogen concentration of a spring wheat crop grown in the northern Negev for two subsequent seasons.

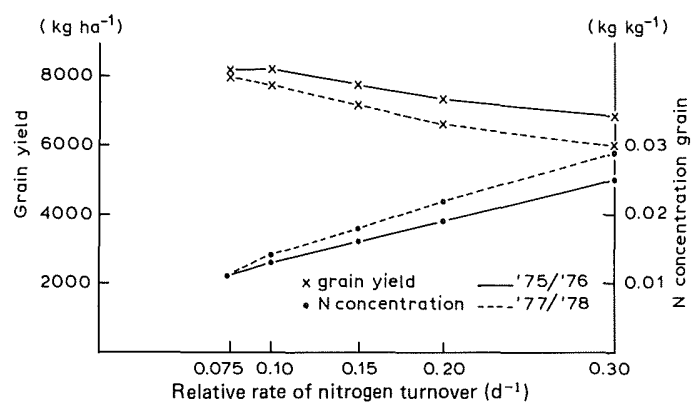


grains with an eye on baking quality an investigation into the genetic variability in nitrogen turnover rates in the crop canopy would be of interest.

The ontogenetic life span of the leaves

It appears that there is a strong interaction between the life span of the leaves and the crop's nitrogen economy. The ontogenetic life span of the leaves only plays a role under conditions of high nitrogen supply so that leaf death is not influenced by translocation of nitrogen from the vegetative tissues.

In the model leaves are assumed to function for 50 days at $15^{\circ} \mathrm{C}$, that is a thermal time of $750^{\circ} \mathrm{C} \mathrm{d}$ for a base temperature of $0^{\circ} \mathrm{C}$.

The two seasons illustrated in Fig. 5.6 differ in their reaction to increased leaf longevity: in 1976-77 longer leaf activity increased both total dry matter production and grain yield but hardly affected the harvest index. On the other hand in 1977-78 increased leaf longevity hardly affected either grain, or total dry matter production. Why there should be this difference between the two seasons is not clear.

An interesting observation from the model results is, however, that in both seasons the nitrogen harvest index increased substantially with increasing life span of the leaves. In 1976-77 from 0.50 at an average life span of 50 days to 0.60 at a life span of 70 days; for $1977-78$ the values were 0.53 and 0.63 , respectively. The longer active life of the leaves permits prolonged translocation of nitrogen to the growing grains and hence a more 'efficient' use of the element. This is also borne out by the nitrogen concentration in the vegetative tissue at maturity, that was $0.014-0.015 \mathrm{~kg}$ $\mathrm{kg}^{-1}$ at a life span of 50 days and 0.011 when the life span of the leaves was 70 days.

Thus, greater leaf longevity creates a situation where, in contrast to the effect of increased nitrogen turnover, increased grain yields are accompanied by higher nitrogen concentrations in the grain. Whether such variability is present in the gene

Fig. 5.7. The simulated relation between grain yield and nitrogen concentration in the grain of a spring wheat crop grown in the northern Negev for four subsequent seasons.

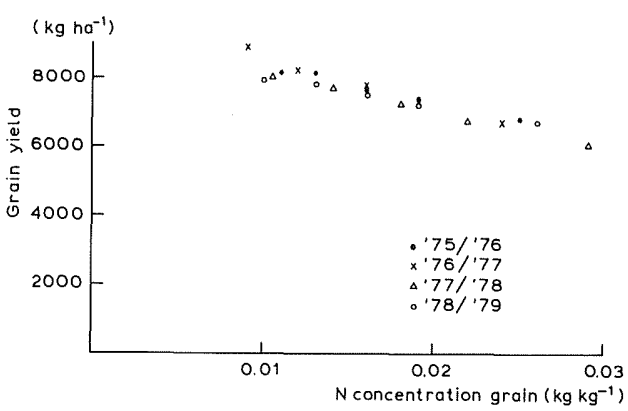


pool is difficult to judge, but the effect should be similar when growth under relatively cool conditions is compared with growth under relatively warm conditions (Spiertz \& Ellen, 1978).

\section{Concluding remarks}

Despite the enormous amount of work that has been done on the subject and the associated proliferation of available literature, large gaps in our understanding of important basic processes still exist.

It would seem that only systems analysis, in which an attempt is made to 'put things together' within a coherent framework, is a research tool that leads to the explicit expression of such lack of knowledge.

Moreover, such an analysis may help in formulating goals for plant breeders: the data in Fig. 5.1 and 5.2 indicate that substantial variability exists in the relationship between assimilation and nitrogen concentration at the individual leaf level. That could be a trait to be pursued by plant breeders. Breeding for increased leaf longevity leading to higher grain and protein yields, could be another aim for plant breeders.

\section{REFERENCES}

Alberda, Th. (1965). The influence of temperature, light intensity and nitrate concentration on dry-matter production and chemical composition of Lolium perenne L. Netherlands Journal of agricultural Science, 13, 335-60.

Angus, J.F. \& Moncur, M.W. (1977). Water stress and phenology in wheat. Australian Journal of agricultural Research, 28, 177-81

Asana, R.D. \& Basu, R.N. (1963). Studies in physiological analysis of yield. VI. Analysis of the effect of water stress on grain development in wheat. Indian Journal of Plant Physiology, 6, 1-13.

Aspinall, D. (1961). The control of tillering in the barley plant. I. The pattern of tillering and its relation to nutrient supply. Australian Journal of biological Sciences, 14, 493-503.

Black, C.A. (1966). Crop yields in relation to water supply and soil fertility. In Plant environment and Efficient Water Use, eds. W.H. Pierre, D. Kirkham, J. Pesek \& R. Shaw, pp. 177-206. American Society of Agronomy, Soil Science Society of America, Madison, Wisconsin

Boatwright, G.O. \& Haas, H.J. (1961). Development and composition of spring wheat as influenced by nitrogen and phosphorus fertilisation. Agronomy Journal, $53,33-6$.

Bolton, J.K. \& Brown, R.H. (1980). Photosynthesis of grass species differing in carbon dioxide fixation pathways. V. Response of Panicum maximum, Panicum milioides and tall fescue (Festuca arundinacea) to nitrogen nutrition. Plant Physiology, 66, 97-100.

Boon-Long, P., Egli, D.B. \& Leggett, J.E. (1983). Leaf N and photosynthesis during reproductive growth in soybeans. Crop Science, 23, 617-620.

Boote, K.J., Gallaher, R.N., Robertson, W.K., Hinson, K., \& Hammond, L.C. (1978). Effect of foliar fertilization on photosynthesis, leaf nutrition, and yield of soybeans. Agronomy Journal, 70, 787-91.

Brouwer, R. (1962). Nutritive influences on the distribution of dry matter in the plant. Netherlands Journal of agricultural Science. 10, 399-408. 
Brouwer, R. (1963). Some aspects of the equilibrium between overground and underground plant parts. Jaarboek Instituut voor Biologisch en Scheikundig Onderzoek van Landbouwgewassen, 1962, 31-9.

Brouwer, R. (1965). Root growth of grasses and cereals. In: The Growth of Cereals and Grasses. eds. F.L. Milthorpe \& J.D. Ivins. London: Butterworths. pp. 153-66.

Brouwer, R., Jenneskens, P.J. \& Borggreve, G.J. (1962). Growth responses of shoots and roots to interruptions in the nitrogen supply. Jaarboek Instituut voor Biologisch en Scheikundig Onderzoek van Landbouwgewassen, 1961, 29-36.

Brown, R.H. \& Wilson, J.R. (1983). Nitrogen response of Panicum species differing in $\mathrm{CO}_{2}$ fixation pathways. II. $\mathrm{CO}_{2}$ exchange characteristics. Crop Science, 23, 1154-9.

Burg, P.F.J. van, (1962). Internal Nitrogen Balance, Production of Dry Matter and Ageing of Herbage and Grass. Verslagen van landbouwkundige Onderzoekingen (Agricultural Research Reports) 68.12. Wageningen: Pudoc.

Campbell, C.A., Davidson, H.R. \& McCaig, T.N., (1983). Disposition of nitrogen and soluble sugars in Manitou spring wheat as influenced by $\mathrm{N}$ fertilizer, temperature, and duration and stage of moisture stess. Canadian Journal of Plant Science, 63, 73-90.

Campbell, C.A., Davidson, H.R. \& Warder, F.G. (1977). Effects of fertilizer N and soil moisture on yield, yield components, protein content and $\mathrm{N}$ accumulation in the aboveground parts of sping wheat. Canadian Journal of Soil Science, 57, 311-27.

Colman, R.L. \& Lazenby, A. (1970). Factors affecting the response of some tropical and temperate grasses to fertilizer nitrogen. In Proceedings 11th International Grassland Congress, Surfers Paradise, ed. M.J.T. Norman, St Lucia: University of Queensland Press. pp. 392-7.

Cook, M.G. \& Evans, L.T. (1983a). Nutrient responses of seedlings of wild and cultivated Oryza species. Field Crops Research, 6, 205-18.

Cook, M.G. \& Evans, L.T. (1983b). Some physiological aspects of the domestication and improvement of rice (Oryza spp.). Field Crops Research, 6 , 219-38.

Dalling, M.J., Boland, G. \& Wilson, J.H. (1976). Relation between acid proteinase activity and redistribution of nitrogen during grain development in wheat. Australian Journal of Plant Physiology, 3, 721-30.

Dantuma, G. (1973). Photosynthesis in leaves of wheat and barley. Netherlands Journal of agricultural Science, 21, 188-98.

Dilz, K. (1964). On the Optimum Nitrogen Nutrition of Cereals. Verslagen van landbouwkundige Onderzoekingen (Agricultural Research Reports), 641 Wageningen: Pudoc.

Dobben, W.H. van (1960). Some observations on the nitrogen uptake of spring wheat and poppies in relation to growth. Jaarboek Instituut voor Biologisch en Scheikundig Onderzoek van Landbouwgewassen, 1959, 93-105.

Dobben, W.H. van (1962a). Influence of temperature and light conditions on drymatter distribution, development rate and yield in arable crops. Netherlands Journal of agricultural Science, 10, 377-89.

Dobben, W.H. van $(1962 b)$. Nitrogen uptake of spring wheat and poppies in relation to growth and development. Jaarboek Instituut voor Biologisch en Scheikundig Onderzoek van Landbouwgewassen, 1961, 45-60.

Dobben, W.H. van (1963). The distribution of dry matter in cereals in relation to nitrogen nutrition. Jaarboek Instituut voor Biologisch en Scheikundig Onderzoek van Landbouwgewassen, 1962, 77-89.

Donovan, G.R. \& Lee, J.W. (1977). The growth of detached wheat heads in liquid culture. Plant Science Letters, 9, 107-13. 
Donovan, G.R. \& Lee, J.W. (1978). Effect of nitrogen source on grain development in detached wheat heads in liquid culture. Australian Journal of Plant Physiology, 5, 81-7.

Fischer, R.A. \& Kohn, G.D. (1966). The relationship of grain yield to vegetative growth and post-flowering leaf area in the wheat crop under conditions of limited soil moisture. Australian Journal of agricultural Research, 17, 281-95.

Gajri, P.R. \& Prihar, S.S. (1985). Rooting, water use and yield relations in wheat on loamy sand and sandy loam soils. Field Crops Research, 12, 115-32.

Goudriaan, J. \& van Keulen, H. (1979). The direct and indirect effects of nitrogen shortage on photosynthesis and transpiration in maize and sunflower. Netherlands Journal of agricultural Science, 27, 227-34.

Goudriaan, J. \& H.H. van Laar, H.H. (1978). Relations between leaf resistance, $\mathrm{CO}_{2}$-concentraion and $\mathrm{CO}_{2}$-assimilation in maize, beans, lalang grass and sunflower. Photosynthetica, 12, 241-9.

Greenwood, D.J. (1982). Modelling of crop response to nitrogen fertilizer. Philosophical Transactions of the Royal Society, Series B 296, 351-62.

Greenwood, E.A.N. (1966). Nitrogen stress in wheat - its measurement and relation to leaf nitrogen. Plant and Soil, 24, 279-88.

Greenwood, E.A.N. \& Titmanis, Z.V. (1966). The effect of age on nitrogen stress and its relation to leaf nitrogen and leaf elongation in a grass. Plant and Soil, 24, $379-89$.

Halse, N.J., Greenwood, E.A.N., Lapins, P. \& Boundy, C.A.P. (1969). An analysis of the effects of nitrogen deficiency on the growth and yield of a western Australian wheat crop. Australian Journal of agricultural Research, 20, 987-98.

Hanson, A.D. \& Hitz, W.D. (1983). Whole-plant response to water deficits: Water deficits and the nitrogen economy. In: Limitations of Efficient Water Use in Crop Production. eds. H.M. Taylor, W.R. Jordan \& T.R. Sinclair. American Society of Agronomy Monograph, Madison, Wisconsin: American Society of Agronomy. pp. 331-43.

Hochman, Z. (1982). Effect of water stress with phasic development on yield of wheat grown in a semi-arid environment. Field Crops Research, 5, 55-67.

Huffaker, R.C. \& Peterson, L.W. (1974). Protein turnover in plants and possible means of its regulation. Annual Review of Plant Physiology, 25, 363-92.

Ishihara, K., Ebara, H., Hirawasa, T. \& Ogura, T. (1978). The relationship between environmental factors and behaviour of stomata in the rice plants. VII. The relation between nitrogen content in leaf blades and stomatal aperture. Japanese Journal of Crop Science, 47, 664-73.

Keulen, H. van (1975). Simulation of Water Use and Herbage Growth in Arid Regions. Simulation Monographs. Wageningen, Pudoc.

Keulen, H. van (1977). Nitrogen Requirements of Rice with Special Reference to Java. Contributions of the Central Research Institute for Agriculture Bogor 30. Bogor, Indonesia: Central Research Institute for Agriculture.

Keulen, H. van (1981) Modelling the interaction of water and nitrogen. Plant and Soil, 58, 205-29.

Keulen, H. van (1986). Crop yield and nutrient requirements. In Modelling of Agricultural Production: Weather, Soils and Crops. eds. H. van Keulen \& J. Wolf. Simulation Monographs. Wageningen : Pudoc. pp 155-181.

Keulen, H. van \& Seligman, N.G. (1987). Simulation of Water Use, Nitrogen Nutrition and Growth of a Spring Wheat Crop. Simulation Monographs. Wageningen:Pudoc.

Keulen, H. van \& van Heemst, H.D.J.(1982) Crop Response to the Supply of Macronutrients. Verslagen van landbouwkundige Onderzoekingen (Agricultural Research Reports) 916. Wageningen:Pudoc. 
Keulen, H. van, Seligman, N.G. \& Goudriaan, J. (1975). Availability of anions in the growth medium to roots of an actively growing plant. Netherlands Journal of agricultural Science, 23, 131-8.

Keulen, H. van, Seligman, N.G. \& Benjamin, R.W. (1981). Simulation of water use and herbage growth in arid regions - A re-evaluation and further development of the model 'Arid Crop'. Agricultural Systems, 6, 159-93.

Khan, M.A. \& Tsunoda, S. (1970a). Evolutionary trends in leaf photosynthesis and related leaf characters among cultivated wheat species and its wild relatives. Japanese Journal of Breeding, 20, 133-40.

Khan, M.A. \& Tsunoda, S. (1970b). Differences in leaf photosynthesis and leaf transpiration rate among six commercial wheat varieties of west Pakistan. Japanese Journal of Breeding, 20, 344-50.

Kramer, Th. (1979). Yield-protein relationship in cereal varieties. In: Crop Physiology and Cereal Breeding, eds. J.H.J. Spiertz \& Th. Kramer, Wageningen:Pudoc. pp. 161-5.

Lof, H. (1976). Water Use Efficiency and Competition Between Arid Zone Annuals, Especially the Grasses Phalaris minor and Hordeum murinum. Verslagen van landbouwkundige Onderzoekingen (Agricultural Research Reports) 853. Wageningen:Pudoc.

Loustalot, A.J., Gilbert, S.G. \& Drosdoff, A. (1950). The effect of nitrogen and potassium levels in tung seedlings on growth, apparent photosynthesis and carbohydrate composition. Plant Physiology, 25, $394-412$.

Lugg, D.G. \& Sinclair, T.R. (1981). Seasonal changes in photosynthesis of fieldgrown soybean leaflets. 2. Relation to nitrogen content. Photosynthetica, 15, $138-44$.

Lupton, F.G.H., Oliver, R.H., Ellis, F.B., Barnes, B.T., Howse, K.R., Welbank, P.J., Taylor, P.J. (1974). Root and shoot growth of semi-dwarf and taller winter wheats. Annals of applied Biology, 72, 129-44.

Marshall, B. (1978). Leaf and Ear Photosynthesis of Winter Wheat crops. PhD Thesis, University of Nottingham.

Martin, R.J. \& Dougherty, C.T. (1975). Diurnal variation of water potential of wheat under contrasting weather conditions. New Zealand Journal of agricultural Research, 18, 145-8.

McLean, E.O. (1957). Plant growth and uptake of nutrients as influenced by levels of nitrogen. Soil Science Society of America Proceedings, 21, 219-22.

McNeal, F.H., Berg, M.A., Watson, C.A. (1966). Nitrogen and dry matter in five spring wheat varieties at successive stages of development. Agronomy Journal, $58,605-8$.

Mesdag, J. (1979). Genetic variation in grain yield and protein content of spring wheat (Triticum aestivum L.). In Crop Physiology and Cereal Breeding, eds. J.H.J. Spiertz \& Th. Kramer, Wageningen:Pudoc., P.J. pp. 166-7.

Mooney, H.A., Ferrar, P.J. \& Slatyer, R.O. (1978). Photosynthetic capacity and carbon allocation patterns in diverse growth forms of Eucalyptus. Oecologia (Berlin), 36, 103-11.

Nair, T.V.R., Grover H.L. \& Abrol, Y.P. (1978). Nitrogen metabolism of the upper three leaf blades of wheat at different soil nitrogen levels. II. Protease activity and mobilization of reduced nitrogen to the developing grains. Physiologia Plantarum, 42, 293-300.

Nevins, D.J. \& Loomis, R.S. (1970). Nitrogen nutrition and photosynthesis in sugar beet. Crop Science, 10, 21-5.

Os, A.J. van (1967). The influence of nitrogen supply on the distribution of dry matter in spring rye. Jaarboek Instituut voor Biologisch en Scheikundig Onderzoek van Landbouwgewassen, 1966, 51-65.

Osman, A.M. \& Milthorpe, F.L. (1971). Photosynthesis of wheat leaves in relation to age, illuminance and nutrient supply. II. Results. Photosynthetica, 5, 61-70. 
Osman, A.M., Goodman, P.J. \& Cooper, J.P. (1977). The effects of nitrogen, phosphorus and potassium on rates of growth and photosynthesis in wheat. Photosynthetica, 11, 66-75.

Penning de Vries, F.W.T. (1974). Substrate utilization and respiration in relation to growth and maintenance in higher plants. Netherlands Journal of agricultural Science, 22, 40-4.

Penning de Vries, F.W.T. (1975). The cost of maintenance processes in plant cells. Annals of Botany (London), 39, 77-92.

Penning de Vries, F.W.T., Brunsting, A.H.M \& van Laar, H.H. (1974). Products, requirements and efficiency of biosynthesis: a quantitative approach. Journal of theoretical Biology, 45, 339-77.

Pinthus, M.J. \& Millet, E. (1978). Interactions among number of spikelets, number of grains and grain weight in the spikes of wheat (Triticum aestivum L.). Annals of Botany 42, 839-48.

Prins, W.H., Rauw, G.J.G., Postmus, J. (1981). Very high application of nitrogen fertilizer on grassland and residual effects in the following season. Fertilizer Research 2, 309-27.

Radin, J.W. (1981). Water relations of cotton plants under nitrogen deficiency. IV Leaf senescence during drought and its relation to stomatal closure. Physiologia Plantarum, 51, 145-9.

Radin, J.W. (1983). Control of plant growth by nitrogen: difference between cereals and broadleaf species. Plant Cell and Environment 6, 65-8.

Radin, J.W. \& Ackerson, R.C. (1981). Water relations of cotton plants under nitrogen deficiency. III. Stomatal conductance, photosynthesis, and abscisic acid accumulation during drought. Plant Physiology, 67, 115-19.

Radin, J.W. \& Boyer, J.S. (1982). Control of leaf expansion by nitrogen nutrition in sunflower plants: role of hydraulic conductivity and turgor. Plant Physiology 69, 771-5.

Radin, J.W. \& Parker, L.L.(1979a). Water relations of cotton plants under nitrogen deficiency. I. Dependence upon leaf structure. Plant Physiology, 64, 495-8.

Radin, J.W. \& Parker, L.L. $(1979 b)$. Water relations of cotton plants under nitrogen stress. II. Environmental interactions on stomata. Plant Physiology, 64, 499-501.

Ryle, G.J.A. \& Hesketh, J.D. (1969). Carbon dioxide uptake in nitrogen-deficient plants. Crop Science, 9, 451-4.

Seligman, N.G., Loomis, R.S., Burke, J. \& Abshahi, A. (1983). Nitrogen nutrition and phenological development in field-grown wheat. Journal of agricultural Science, 101, 691-7.

Seligman, N.G., van Keulen, H., Yulzari, A., Yonathan, R., Benjamin, R.W. (1976). The Effect of Abundant Nitrogen Fertilizer Application on the Seasonal Change in Mineral Concentration in Annual Mediterranean Pasture Species. Preliminary Report 754.Bet Dagan, Israel: Division of Scientific Publications.

Shimshi, D.(1970a). The effect of nitrogen supply on some indices of plant-water relations of beans (Phaseolus vulgaris L.). New Phytologist, 69, 413-24.

Shimshi, D. (1970b). The effect of nitrogen supply on transpiration and stomatal behaviour of beans (Phaseolus vulgaris L.). New Phytologist, 69, 405-13.

Shimshi, D. \& Kafkafi, U. (1978). The effect of supplemental irrigation and nitrogen fertilisation on wheat (Triticum aestivum L.). Irrigation Science, 1 , $27-38$.

Sofield, I., Wardlaw, I.F., Evans, L.T., Zee, S.Y. (1977). Nitrogen, phosphorus and water contents during grain development and maturation in wheat. Australian Journal of Plant Physiology, 4, 799-810.

Spiertz, J.H.H. \& Ellen, J.(1978). Effects of nitrogen on crop development and grain growth of winter wheat in relation to assimilation and utilisation of 
assimilates and nutrients. Netherlands Journal of agricultural Science, 26, 210-31.

Sunderland, N. (1960). Cell division and expansion in the growth of the leaf. Journal of experimental Botany 11, 68-80.

Takeda, T. (1961). Studies on the photosynthesis and production of dry matter in the community of rice plants. Japanese Journal of Botany, 17, 403-37.

Tanner, C.B. \& Sinclair, T.R. (1983). Efficient water use in crop production: Research or re-search. In Limitations of Efficient Water Use in Crop Production. eds. H.M. Taylor, W.R. Jordan \& T.R. Sinclair. American Society of Agronomy Monograph. Madison, Wisconsin: American Society of Agronomy, pp. 1-27.

Viets, F.G. Jr. (1962). Fertilizers and the efficient use of water. Advances in Agronomy, 14, 223-64.

Vos, J. (1981). Effects of Temperature and Nitrogen Supply on Post-floral Growth of Wheat; Measurements and Simulations. Verslagen van Landbouwkundige Onderzoekingen (Agricultural Research Reports) 911. Wageningen:Pudoc.

Wilson, J.R. (1975a). Influence of temperature and nitrogen on growth, photosynthesis and accumulation of non-structural carbohydrate in a tropical grass, Panicum maximum var. trichoglume. Netherlands Journal of agricultural Science, 23, 48-61.

Wilson, J.R. (1975b). Comparative response to nitrogen deficiency of a tropical and temperate grass in the interrelation between photosynthesis, growth, and the accumulation of non-structural carbohydrate. Netherlands Journal of agricultural Science, 23, 104-12.

Wilson, J.R. \& Haydock, (1971). The comparative response of tropical and temperate grasses to varying levels of nitrogen and phosphorus nutrition. Australian Journal of agricultural Research, 22, 573-87.

Wit, C.T. de (1958). Transpiration and Crop Yields. Verslagen van landbouwkundige Onderzoekingen (Agricultural Research Reports) 64.8 Wageningen:Pudoc.

Wit, C.T. de et al.(1978). Simulation of Assimilation, Respiration and Transpiration of Crops. Simulation Monographs. Wageningen:Pudoc.

Woledge, J. \& Pearse, P.J. (1985). The effect of nitrogenous fertilizer on the photosynthesis of leaves of a ryegrass sward. Grass and Forage Science $\mathbf{4 0}$ 306-9.

Wong, S.C. (1979). Elevated atmospheric partial pressure of $\mathrm{CO}_{2}$ and plant growth.I. Interactions of nitrogen nutrition and photosynthetic capacity in $\mathrm{C}_{3}$ and $\mathrm{C}_{4}$ plants. Oecologia (Berlin), 44, 68-74.

Wong, S.C., Cowan, I.R. \& Farquhar, G.D. (1979). Stomatal conductance correlates with photosynthetic capacity. Nature, 282, 424-6.

Yoshida, S. \& Coronel, V.(1976). Nitrogen nutrition, leaf resistance and leaf photosynthetic rate of the rice plant. Soil Science and Plant Nutrition, 22, 207-11.

Yoshida, S. \& Hayakawa,Y. (1970). Effects of mineral nutrition on tillering of rice. Soil Science and Plant Nutrition, 16, 186-91. 